\title{
24-Öncesi ve sonrası ile felsefe ve edebiyatta vicdani sistem
}

\section{Seda ARIKAN1}

\begin{abstract}
APA: Arıkan, S. (2020). Öncesi ve sonrası ile felsefe ve edebiyatta vicdani sistem. RumeliDE Dil ve Edebiyat Araştırmaları Dergisi, (21), 406-423. DOI: 10.29000/rumelide.835775.
\end{abstract}

\section{$\ddot{\mathbf{O} z}$}

Vicdan, genelde felsefenin özelde ise ahlak felsefesinin her yüzyılda farklı yaklaşımlarla ele aldığı bir kavram olarak günümüz felsefe çalışmalarında da güncelliğini korumaktadır. Kişinin doğruya ve iyiye niyet etme ve bu değerler ışı̆̆ında eyleme geçme kapasitesi olarak vicdanın soyut bir kavram olmaktan ziyade somut bir sistem olduğu unutulmamalıdır. Üzerine düşünülen veya düşünmeden anlık olarak gerçekleştirdiğimiz çoğu karar ve eylemimiz aslında vicdani sistem işleyişinin sonuçları olarak ortaya çıkmaktadır. Bu bağlamda, bu çalışma genel olarak vicdani sistemin nasıl bir mekanizma ile işlediğini, bu mekanizmayı oluşturan etmenleri, vicdani sistemin işleyişinde akıl, sezgi ve üst aklın gerektiği ve yetersiz kaldı̆̆ı noktaları çeşitli felsefi yaklaşımlar ile irdelemeyi amaçlamaktadır. Vicdani sistemi öncesi ve sonrası ile değerlendirmek bu sistemi sadece eylemden önce ortaya çıkan bir karar alma süreci olarak değil, eylemden sonra devam eden bir ahlaki sorgulama sistemi olarak görmeyi gerektirmektedir. Bu bağlamda, vicdani muhasebe ile işleyen bir vicdani sistem akıl ve duygulardan bağımsız bir mekanizma olmamakla birlikte insanı ruhsal bir tutsaklık ya da özgürlüğe götürecek hayati bir işleyiştir. Bu çalışma, vicdani sistemin tekli bir mekanizma ile değil, çoğulcu işleyiş ile insanın aklı ve duygularıyla bağlantılı olarak nasıl ortaya çıktığını felsefi yaklaşımlar bağlamında ele alırken, edebiyatın soyut kavramları somutlaştıran doğasından faydalanarak vicdani işleyişin insan hayatındaki bazı yansımalarına ışık tutmayı amaçlamaktadır.

Anahtar kelimeler: Vicdani sistem, akıl, sezgi, duygu, özgürlük, edebiyat

\section{The system of conscience with its pre and post in philosophy and literature}

\begin{abstract}
Conscience, a concept that has been dealt by philosophy, in general, and moral philosophy, in particular, in each century with different approaches keeps up-to-date in today's philosophical studies. It should not be neglected that conscience is a concrete system rather than being an abstract concept as it is a capacity of a person to intend the right and the good, and to get into the action in the light of these values. Many of our decisions and actions that are thought on or carried out momentarily without thinking actually appear as the outcomes of the working of the system of conscience. In this respect, as a whole, this study aims to examine within various philosophical approaches what a kind of mechanism the system of conscience works with, the elements forming this mechanism, the points where reason, intuition and mastermind are required or fall behind. To assess the system of conscience with its pre and post requires to accept this system not only as a decision-making process before going into action but also a system of moral questioning that proceeds after the action. In this sense, besides the system of conscience operating with
\end{abstract}

\footnotetext{
$1 \quad$ Doç. Dr., Fırat Üniversitesi, İnsani ve Sosyal Bilimler Fakültesi, Batı Dilleri ve Edebiyatları Bölümü, İngiliz Dili ve Edebiyatı ABD (Elazı̆̆, Türkiye), bulutsedaaarikan@gmail.com, ORCID ID: oooo-0003-4190-9205 [Araştırma makalesi, Makale kayıt tarihi: 27.10.2020-kabul tarihi: 20.12.2020; DOI: 10.29000/rumelide.835775]

Adres | Address

İstanbul Medeniyet Üniversitesi, Eğitim Bilimleri Fakültesi, Türkçe ve Sosyal Bilimler Eğitimi Bölümü, Türkçe Eğitimi ABD Cevizli Turkish and Social Scinces Education, Turkish Language Teaching Kampüsü, Kartal-İstanbul/TÜRKIYE $\quad$ Education, Cevizli Campus, Kartal-İstanbul /TURKEY e-posta: editor@rumelide.com $\mid$ e-mail: editor@rumelide.com
} 
conscientious questioning is not a mechanism independent from reason and emotions, it is a vital operation that would lead people to confinement or freedom. This study, while dealing with how the system of conscience appears not within a monist mechanism but within multiple workings in relation to human reason and emotions-in terms of philosophical approaches-, it aims to illuminate the reflections of the system of conscience in human life by using the nature of literature that concretize the abstract concepts.

Keywords: The conscience system, reason, intuition, emotion, freedom, literature

\section{Giriş}

Bir karara varmak ya da varamamak ve bununla ilintili olarak vicdani his-olumlu ya da olumsuzvicdani sistemin işleyişiyle bağlantılıdır. Vicdani sistem, vicdan tartışmalarında sıklıkla dile getirilen insandaki en temel iki diğer işleyişin söz konusu olmasına neden olur; zihinsel ve duygusal işleyiş. Aslında zihne ya da akla yapılan göndermeler ile duygular ya da başka bir deyişle "kalbe" yapılan göndermeler vicdan tartışmalarında temel referans kaynakları olmuştur. Bu durumda, vicdani sistemin nasıl geliştiği ve işlediği sorularına verilen yanıtlar zihinsel ve duygusal işleyiş fikirlerine paralel gibi görünmektedir. Vicdani sistemin gelişimini zihinsel bir ilerleme, gelişme ya da var olan zihinsel kapasitenin kullanımı olarak görenler, vicdanın akıl ile olan bağlantısına vurgu yaparken vicdanı insanda bizatihi var olan bir tür sezgiye ya da içtepiye dayandıranlar daha çok onun duygusal ve sezgisel işleyişini ön plana çıkarırlar. Nitekim akıl ile kalbin çatışması vicdani sistemin işleyişini tanımlamadaki günlük kullanımlarda da kendini gösterir. Örneğin "kalpsiz" kavramı "vicdansız" olanı tanımlamak için sıklıkla kullanılır. Aklımızın onaylamadığı bir durumda bile "vicdan yapmamız" kalben o durumu onaylamadığımız anlamına gelir. Peki, vicdani sistemin işleyişinde fikri ya da hissi yanımızdan hangisi ağır basmalıdır? Bu soruya antik çağdan itibaren felsefecilerin ve düşünürlerin farklı yanıtlar vermesi aslında çok da kolay bir kavramla karşı karşıya olmadığımızın en açık göstergesi olsa gerek...

\section{Vicdani sistemin işleyişinde akıl, sezgi ve üstakıl}

\section{1.a. Vicdani sistemin işleyişinde akıl}

Shakespeare'in zamana ve mekâna meydan okuyan eseri Hamlet (1603 [1995]), çok temel bir vicdani sorgulama üzerine kurulmuştur: Öldürmek ya da öldürmemek. Amcası Claudius'un babasının katline gerçekten sebep olup olmadığını "bilmek" isteyen Hamlet, oyun boyunca akli muhakemeler yapar. İntikam isteği ile mezarından çıkıp gelen babasının hayaleti karşısında bile akli muhakemelere gitmeden karar vermeyen Hamlet, bu durumda ne kadar vicdanının sesini dinler? Kimileri buna "hiç" diyerek cevap verebilir; eğer vicdan ile kalbi ve hissi olanı anlamaya daha yakınsa... Oysa Hamlet, vicdani sistemin işleyişinde aklı ön plana çıkaran düşünürlerin takdir edeceği bir şekilde davranır. Bir Rönesans adamı olarak hümanizm ideallerinin insan aklını ön plana çıkaran eğitiminden geçmiş Hamlet, ilk andan itibaren düşünür.

Özellikle orta çağda sıklıkla tartışılan bir konu olarak vicdan, orta çă̆ felsefecileri tarafından iki yönü ile ele alınır: a) conscientia, yani eylemlerimiz hakkında verdiğimiz yargllar b) syneidesis, insan doğasında var olan ayrılamaz ve yanılmaz temel. Conscientia hem içe hem dışa bağlı olarak verilen vicdani kararlara gönderme yaparken syneidesis pratik akıl yürütmenin ilk öncülleri olan temel ahlaki prensipleri anlatır; bu durumda syneidesis yanılmaz bir karaktere sahipken conscientia yanlış akıl

Adres

İstanbul Medeniyet Üniversitesi, Eğitim Bilimleri Fakültesi, Türkce ve Sosyal Bilimler Eğitimi Bölümü, Türkçe Eğitimi ABD Cevizli Kampüsü, Kartal-İstanbul/TÜRKIYY e-posta: editor@rumelide.com
Address

İstanbul Medeniyet University, Faculty of Education Sciences,

Turkish and Social Scinces Education, Turkish Language Teaching

Education, Cevizli Campus, Kartal-İstanbul /TURKEY

e-mail: editor@rumelide.com 
yürütmeler sonucu hatalı sonuçlar verebilir. Çünkü syneidesis insanda var olan içsel bir nitelik iken, conscientia kamunun beklentilerine ve kamu alanına aittir (Strohm, 2011, s.8). Bu görüşe yaklaşan Thomas Aquinas'a göre vicdan, insan aklının bir eylemidir; dış etkilerden ziyade düşünme ile gelişen, onu takip eden ve onunla sonuçlanan bir tür muhakemedir. Tipkı Hamlet’in zihinsel süreçleri gibi...

On altıncı yüzyıldan başlayarak sekülerleşmenin etkisiyle vicdan, Tanrı’nın sesi ve gücü olmaktan çıkar. Vicdanın artık aklın sesi olduğu fikri özellikle on yedinci ve on sekizinci yüzyllarda rasyonel felsefecilerin savunduğu bir görüştür. Bir sonraki yüzyılda ise Kant ve onun ahlak felsefesi bizler için vicdanı akli boyutuyla anlamak açısından devrim niteliğindedir. Kant ahlaki bir varlık olarak her bireyin özünde vicdan olduğunu savunur (Kant, 1797 [1991], s.160). Fakat Kant'in bu görüşünün vicdanı bir tür hissi güdülenme olarak görenlerden oldukça farklı olduğu unutulmamalıdır. Kant, vicdanı ödev fikri bağlamında ve zihnin dört doğal eğiliminden biri olarak kabul ederken onu doğrudan zihinsel sürecin bir parçası, aklın vazgeçilmez yandaşı olarak görür. Tıpkı diğer üç eğilim gibi-ahlaki his, komşularına karşı sevgi duymak ve özsaygı (Kant, 1797 [1991], s.160)-vicdan da akletmekten ayrı bir işleyişle bağlantılı değildir. Kant’ın vicdan ile gelen hisleri olumlu olarak görmesinin nedeni de bu olsa gerek... Kişinin vicdanına uyarak ve doğru kararlar vererek hareket ettiği fikrinden yola çıkan Kant, vicdanı daha çok olumlu hislerle bağdaştırır; bu durumda fail, ödev duygusu ile aklederek vicdanı rahat bir şekilde hareket etmiş olur. Yani bireyin bilincindeki ahlaki yükümlülük hissi (Fuss, 1964, s.116) ile...

Bu şekilde ele alınan bir vicdan, aklın epistemik işleyişini vicdani sistemin işleyişi ile bağlantılı görür. Ahlaki bilgiye ulaşmamızı sağlayan, doğru/yanlış ya da iyi/kötü nedir'in bilgisini veren vicdani muhakemeler akılsal süreç ile ortaya çıkar. Peki vicdan doğrudan bir ahlaki bilgi yetisi mi, yoksa doğrudan olmasa da kişiyi iç muhakemeye yönlendiren ve böylece zihinsel süreçleri etkileyen bir bilgi yetisi midir? Bu iki görüş en temelde doğa/kültür karşıtllğının tartışma alanına girer. Doğrudan bir bilgi yetisi olarak vicdanın insanda bizatihi bulunduğunu savunanların yanı sıra, "kökensel bir hafiza olarak iyi ve doğrunun [zamanla] içimize işlendiği”" (Ratzinger, 2010, s.535) fikrinde olanlar da vardır. Tamamen ve kuvvetle bu zıt iki uçta duranlar vicdan tartışmalarında birçok sorunun muhatabı olur. Örneğin, vicdan insanda doğrudan epistemik bir kuvve ise vicdan dışı davrananları hangi kategoriye almalıyız? Belki de bu insanlar akıl dışı kategorisinde değerlendirilmelidir. Peki bu durumda vicdanın gerektirdiği suçluluk ve onaylamama hisleriyle ahlaki bilgilerini ilişkilendiremeyen psikopatların eylemleri bir şekilde meşrulaştırılmış olmaz mı? Bu durumda psikopatlar için akıl dışı davrandıkları söylenerek vicdani yükümlülük ortadan kalkar; fakat bu hemen herkesin vicdanını rahatsız edecektir. Ya da kültürel normlarla kazanılan vicdani sistemin varlığını savunan görüşler, dış faktörlerden bağımsız insanda var olan vicdani his ve eylemlerin varlığını nasıl açılayacaklardır? Doğru bir vicdani öğreti alan bir psikopatın varlığı bu görüşü savunanlar için büyük bir çelişkidir.

İster doğrudan ister dolaylı olsun, aklın epistemik verileriyle hareket eden bir vicdani sistem çoğu düşünürün olması gereken olarak savunduğu bir vicdani işleyiştir. Onlara göre vicdani hatalar epistemik bir kaynağa bağlı olmayan aklın sonucunda ortaya çıkar. Aklın sistematiğine oturan bu görüş oldukça makul görünse de vicdanı doğrudan ahlaki bilgi kuvvesi olmaktan ziyade sezgisel bir işleyiş, ya da kalbi bir duygu olarak ele alanlar da vardır. Kant Critique of Pure Reason'da (1781 [1998]) saf akıl temelli bir ahlaki işleyişi, doğru ve yanlışa akılla ulaşılacağını tartışır. Kant'ın ortaya koyduğu ahlaki ya da vicdani sistemde belirli maksimlere göre hareket eden birey her zaman doğru eyleme yönelecektir. Fakat bu kadar sağlam bir akli sistemde bile insanı vicdani sorgulamalara iten bazı örneklemler vardır. Kant, "yalan söylemeyeceksin” düsturundan yola çıkarak bu kuralın hiçbir şekilde bozulmaması gerektiğini şu örnekle anlatır. Katilinden (bu herhangi bir gangster ya da kötücül

Adres

İstanbul Medeniyet Üniversitesi, Eğitim Bilimleri Fakültesi, Türkce ve Sosyal Bilimler Eğitimi Bölümü, Türkçe Eğitimi ABD Cevizli Kampüsü, Kartal-İstanbul/TÜRKIYE e-posta: editor@rumelide.com
Address

İstanbul Medeniyet University, Faculty of Education Sciences,

Turkish and Social Scinces Education, Turkish Language Teaching

Education, Cevizli Campus, Kartal-İstanbul /TURKEY

e-mail: editor@rumelide.com 
bir kişi de olabilir) kaçan bir adamın evinize sığındığını düşünün. Kapınıza gelen o kişi, evinizde sığınan kişinin katili olacak bir insan bile olsa ona "yalan söylemeyeceksin" ve aranan kişinin evinde olduğunu doğruca söyleyeceksin. Çoğu insan bu durumda içtepkisel olarak hiç öyle şey olur mu fikrine kapılır. Fakat Kant için herhangi bir maksim ne olursa olsun bozulmamalıdır. Aksi takdirde ahlaki ve vicdani zinciri tutan halkalardan biri kopmuş olur. Kant'ın tüm akılcı sistemine rağmen onun katilinden kaçan hipotetik adamını katiline teslim etmek vicdanımızı rahatlatmayacaktır. Tam da bu noktada vicdanın akıl temelli bir kuvve olduğu görüşünden ziyade sezgisel olduğu ve duygular tarafından işletildiği fikri bir zıt kutup olarak ortaya çıkar.

\section{1.b. Vicdani sistemin işleyişinde sezgi}

Vicdanın kökenini sezgi ve duygulara dayandıranlar akılcı tarafta olanlardan hiç de az değildir. Örneğin Rousseau, vicdani sistemin kurulabilmesi için doğuştan gelen vicdani doğruların kültürel ve sosyal şekillendirmelerden kurtarılması gerektiğini kuvvetle savunur. Ona göre, vicdani eylemlerimizde iyi ve kötüyü değerlendirdiğimiz doğuştan gelen bir prensip vardır ve ancak bu içkin prensibi dış etkilerden kurtarırsak saf vicdani yargılara ulaşabiliriz (Rousseau, 1921, s.253). Rousseau'nun insanda doğuştan var olduğuna inandığı bu prensip, insanın temelde kötücül olduğunu savunanlar tarafından ele alındığında sorunsallaşmaya mecburdur. Onlar böyle bir vicdani tanıma karşı çıkacaklardır.

İnsanı dış etkilerden soyutlayıp onun doğasına ulaşmayı amaçlayan William Golding, Sineklerin Tanrısı'nda (1954 [1959]) bu sorunsallaştırmayı bir grup küȩük çocuk üzerinden yapar. Rousseau'nun savunduğu, doğuştan gelen ve iyi ile kötüyü, doğru ile yanlışı birbirinden ayırmaya yardımcı olacak bu vicdani prensip, Golding’in çocuklarında pek de işlemez. Medeniyetin altın çağında ve ülkesinde (İngiltere) yetişmiş bir grup İngiliz çocuk ıssız bir adaya düşüp yaşam mücadelesine girince, iyi-kötü muhakemesi yapmak şöyle dursun en ilkel topluluklardan daha korkutucu hale gelirler. Sineklerin Tanrısı'nda aklın ve ahlakın temsilcisi olan Simon adlı çocuk, "Golding'in ölüm saçan çocukları" tarafından insanoğlunun "körlüğü, akıldışılı̆̆ı ve kana susamışlığının” (Friedman, 2008, s.68) sonucu olarak vahşice öldürülür. Bu durumda insanda doğuştan var olduğuna inanılan vicdani bir prensip ya da sistem görüşüne Golding meydan okumaktadır. Yine de romanda kötücül çocuklara karşın Simon'ın varlığı belki de tüm insanlığı kapsamasa da vicdani sistemi doğasında barındıran kimi insanların varlığına işaret eder.

Vicdani sistemi akıl yerine içsel ve sezgisel kaynaklara dayandıran çalışmalardan bir grubu nörobilim çalışmaları oluşturmaktadır. Ahlak psikolojisindeki kimi teorik çalışmalar nörobilim ile destekli olarak şunu göstermiştir; en temel ahlaki inançlarımız akli kuvvelerimizin çok az etki ettiği sezgi ve duygulara dayanır. Ahlaki davranışa neden olacak bir güdü olarak vicdani sistem görüşü daha çok küçük çocukların hatta bebeklerin vicdani kararları üzerine yapılan çalışmalarda kendini gösterir. Bebeklerin doğuştan gelen ahlaki normlar ile hareket ettiklerini gösteren deneyler böylece vicdanın, sadece Kant’ın bahsettiği içsel bir mahkeme olmadığını, aynı zamanda ahlaki davranma güdümüzün kaynağı olduğunu göstermiş olur.

İnsan doğasıyla ilgili sıklıkla karamsar bir tavır takınan William Golding, uzak bir geçmişi ve medeniyetin kökenini sorgulayan bir başka romanı The Inheritors'da (1955), dünyanın buzul çă̆ındaki dönemlerine kadar giderek Homo Sapienlerin kötücül doğasına tekrar vurgu yapar. Hala Neandertallerin hayatta olduğu bir dönemi anlatan romanda, Homo Sapienlerin gelmesiyle birlikte "masum” Neandertaller için hayat bir kabusa dönüşür. Romanda nörobilimcilerin iddia ettiğinin

\footnotetext{
\begin{tabular}{r|l} 
Adres & $\begin{array}{l}\text { Address } \\
\text { İstanbul Medeniyet Üniversitesi, Eğitim Bilimleri Fakültesi, Türkçe }\end{array}$ \\
İstanbul Medeniyet University, Faculty of Education Sciences,
\end{tabular} ve Sosyal Bilimler Eğitimi Bölümü, Türkçe Eğitimi ABD Cevizli Turkish and Social Scinces Education, Turkish Language Teaching Kampüsü, Kartal-İstanbul/TÜRKIYE Education, Cevizli Campus, Kartal-İstanbul /TURKEY e-posta: editor@rumelide.com $\mid$ e-mail: editor@rumelide.com
} 
aksine Homo Sapienlerde hiç de doğuştan gelen bir vicdani sistem olmadığı̆ görülmektedir. Basit, sezgi ve duygularını kullanarak doğayla uyum içinde yaşayan, canlıları öldürmekten sakınan, bir hayvanın etini ancak o öldükten sonra yiyen Neandertallere karşın Homo Sapienler, Neandertal ailesinin üyelerinden bazılarını öldürüp çocuklarını da kaçırırlar. Dahası, çocuklardan birini törensel bir şekilde öldürüp yerler.

Bu noktada, insanın kültürden arındırılıp kendi doğasına bırakıldığında vicdani yargılardan uzaklaşıp id’in etkisiyle hareket edeceği fikrine nörobilimciler evrim teorisi bağlamında itiraz edebilirler. Çünkü yaklaşı 200,000 yl önce evrilmeye başlayan Homo Sapienlerin bu doğrultuda vicdani sistemlerinin de evrildiğini söylemek mümkündür. The Descent of Man'de (1871 [1981]) Charles Darwin, vicdani gelişim üzerinde durarak hafıza gelişimi ve evrimsel ilerleme ile vicdani gelişimin paralelliğinden bahseder. Şüphesiz evrimsel olarak vicdani gelişimden bahsetmek mümkün; binlerce yll önceki Homo Sapienler olmadığımız aşikâr... Fakat bunun tüm insanları kapsayan bir gelişme olduğunu söylemek günümüzdeki ahlak dışı tüm uygulamalar göz önüne alındığı zaman fazla iyimser gibi görünmektedir. İnsan insanin kurdudur'u onaylayan olaylar dünyada kol geziyor.

Vicdani sistemin doğal olarak insanda doğuştan var olduğunu savunan en güçlü argümanlardan bir diğeri teolojik argümandır. Vicdanın doğuştan, a priori olarak insanda var olduğunu savunan teolojik argümanlar bunu Tanrının varlı̆̆ının kanıtı için teolojik bir tez olarak dile getirirler. Bu noktada, örneğin, vicdan kavramı "klasik İslami metinlerde genellikle epistemolojik bağlamda sezgi anlamında geçmekte"dir ve çoğunlukla "kişinin kendisinde bulduğu bilgi"ye tekabül ederken bu kavram hem epistemik hem de ahlaki açıdan vurgulanır (Cengiz ve Çınar, 2018, s.xiv). Burada altı çizilmesi gereken önemli bir noktayı atlamamak gerekir. Vicdanı, akılsal süreçlerin sonucu olarak gören bazı düşünürler de bu yetinin insanda doğuştan var olduğunu savunurlar. Bu noktada doğuştanlık açısından sezgisel görüşü savunanlarla aynı paydada buluşurlar. Bununla birlikte Kant gibi, aklın belirli kategorilerinde doğuştan var olan vicdanın daha sonra gelişmiş bir vicdani sezgiye dönüştügünü savunanlar da vardır. Yani doğuştanlık ve sezgisellik vicdani sistemi tamamen akıl ile bağlantılı gören kimi düşünürler tarafından da onaylanır. Bu bağlamda, ahlak kurallarının bizatihi insanda var olduğunu düşünenler ya da Locke'un aksine insanın zihninde doğuştan gelen bir vicdani muhakeme olduğunu savunanlar bu ilkelere uyulmadığında ortaya çıkan vicdan azabını argümanlarının en önemli kanıtı olarak görürler (Cevizci, 2015, s.520). Sezgisel görüşü savunanlar da benzer şekilde insanın doğru içsezilere ulaşacak ahlaki ve vicdani bir sistem ile donatıldığı görüşünde diğerlerine yaklaşırlar. Bu durumda, vicdani sistemin kaynağı akıl mıdır sezgiler mi tartışmasında durdukları taraf bu iki bakış açısının birbirinin alternatifi olarak ortaya çıkmasına neden olmuştur. Hangisinin doğru olduğu vicdan tartışmalarında hala süregiden bir konudur.

Vicdani sistemin işleyişinde akıl ya da sezgi ve duyguların itici güç olduğunu savunan iki görüşün yanına bir üçüncüsünü eklemek mümkün. Bu üçüncü güç bir nevi Michel Foucault’nun “iktidar” olarak adlandırdığı otoriter üst akıldır.

\section{1.c. Vicdani sistemin işleyişinde üst akıl}

Rönesansla başlayan ve Aydınlanma Çağı ile devam eden sekülerleşme daha önce Tanrı'nın sesi olarak aşkın bir statü kazandırılan vicdanın seküler alanlarda değerlendirilmesine neden oldu. Tanrı'nın bu dünyadaki yansıması olan hükümdarlar ile feodal düzenlerde ve imparatorluklarda sağlanan iktidar, aslında o topraklarda yaşayan tebaanın vicdani sistemlerinin inşasını da kontrol eden bir mekanizmaydı. On dokuzuncu yüzyıl sonrası devlet yapılanmalarında ise normatif yazılı ya da yazılı

\footnotetext{
\begin{tabular}{r|l} 
Adres & $\begin{array}{l}\text { Address } \\
\text { İstanbul Medeniyet Üniversitesi, Eğitim Bilimleri Fakültesi, Türkçe }\end{array}$ \\
İstanbul Medeniyet University, Faculty of Education Sciences,
\end{tabular} ve Sosyal Bilimler Eğitimi Bölümü, Türkçe Eğitimi ABD Cevizli Turkish and Social Scinces Education, Turkish Language Teaching Kampüsü, Kartal-İstanbul/TÜRKIYE Education, Cevizli Campus, Kartal-İstanbul /TURKEY e-posta: editor@rumelide.com $\mid$ e-mail: editor@rumelide.com
} 
olmayan tüm yasalar iktidarın istenci ve bilinci doğrultusunda oluşturulan belirli vicdani hükümler üzerine oturtulmuştur. Foucault gibi yirminci yüzyll düşünürlerinden çoğu her ne kadar iktidar eliyle oluşturulan vicdani sistemleri eleştirseler de aslında onlardan önceki birçok felsefeci, devletin ya da genel olarak iktidarın vicdani sistem oluşturmadaki rolünü çoğu zaman meşrulaştırmıştır.

Aquinalı Thomas’a göre, devletin önemli görevlerinden biri vicdanlarına göre hareket etmeyen kişilere doğal hukukun zorunluluklarını benimsetmek ve onları bu şekilde disipline etmektir (Cevizci, 2015, s.320). Bu durumda vicdani sistem devlet eliyle kişiye verilen ve bu sistemi işletirken kendi aklını ya da sezgilerini kullanmasına gerek olmadığg fikriyle hareket eden bir tür dışsal mekanizmadır. Benzer bir şekilde "Montesquieu'ya göre [...] hak, adalet ve yükümlülük düşünceleri, insanın doğuştan getirdiği bir vicdan ya da ödev duygusu olmadığına göre, yasayla birlikte zuhur eder" (Cevizci, 2015, s.594). Bu durumda devletin topluma benimsettiği vicdani sistemi destekleyen hak ve adalet gibi erdemler hiç de Aristoteles'in gördüğü gibi insanda var olan ve olması gereken kardinal erdemler değil, dışsal olarak insana benimsetilen vicdani yapılardır. Peki bu durumda yasaya uymayıp vicdan azabı da çekmeyenlere ne demek gerekir? İktidarın onun üzerinde yeterince iyi işlememiş olduğunu mu?

Nietzsche, vicdani sistemin suni bir özgür irade ve vicdan temeline dayandırıldığı görüşünü benimserken bunu köle ahlakı ile açıklar. Ona göre köle ahlakı efendi ahlakının karşısında var olabilmek için özgür irade ve vicdan kavramlarını yaratmıştır. Çünkü ancak bu şekilde kendini efendi ahlakına karşı olumlayabilecektir. Platon'un kurduğu ideal ve ütopik bir devlette iktidarın insanları vicdani bir sistem oluşturmaya yönelttiği söylenebilir. Fakat bugünkü birçok politik devletin iktidarı nasıl bir vicdani sistem kurmak için kullandığı tartışmaya oldukça açık bir konudur. Nitekim siyaset felsefesinin sıklıkla utilitaryen olmaya yönelen doğası bunun bir göstergesidir. İktidarın insanların vicdani sistemlerini kurmasında üstlenmeleri gerektiği rolü eleştiren düşünürlerden biri olan Bergson'a göre ahlak, kapalı ve açık ahlak olarak ikiye ayrılmalıdır (Cevizci, 2015, s.889): Kapalı ahlakta toplum, bireyleri kontrol altına alarak kendi varlığını sürdürmek adına bir ahlaki sistem kurar. Yani Foucault'nun güç istenci savı iş başındadır (Foucault, 1975 [1979], 1980). Bunun karşıtı olan açık ahlak ise bireyin kendi vicdanında oluşan bir ahlak sistemidir ve buna göre, bireyin kendisi vicdani sistemini oluşturmakla yükümlüdür.

Hemen her iktidarı güç istenci ile bağlantılı olarak ele alan Foucaultcu tez ışı̆̆ında düşünüldüğünde, toplum üzerinde yaratılan vicdani sistemlerin iktidarın yönetme, yönlendirme ve kontrol altına alma mekanizmaları olduğunu söylemek yanlış olmayacaktır. George Orwell’ın her dönemin dinamiklerine uyan distopyası 1984 (1949 [1990]), iktidarın nasıl da yanlışlarını doğru olarak insanlara benimsettiğini, onların zihinlerini kontrol altına alarak insanların kendi doğru ve yanlışlarını oluşturabilecekleri ve bu doğru ve yanlışlarla eyleme geçebilecekleri herhangi bir vicdani sistem yaratmalarını nasıl engellediğini anlatır. Günümüzde de hüküm süren baskıcı iktidarlar gibi 1984’teki söz konusu iktidarın herhangi bir düşünce ve vicdan özgürlüğüne müsaade etmeyecek bir sistem kurduğu bu toplumda, vicdani işleyişte ne bireysel aklın ne de sezginin yeri yoktur. Başkarakter Winston Smith’in Doğruluk Bakanlı̆̆ı'nda çalışırken, yaşadı̆̆ Okyanusya toplumuna uygulanan yanlış tutumları sorgulayıp kendi vicdani sistemini işletmeye başlaması onun mahvına neden olacaktır. Bu durumda Bergson'ın açık ahlakından yana olduğu kabul edilebilecek Orwell, vicdani sistemi hiç de devlet ya da diğer iktidarların tekeline verilecek bir sistem olarak görmez. Romanda hak, adalet ve yükümlülük duyguları hiç de Montesquieu'nün dediği gibi yasayla zuhur etmez; ya da etse de bu hak ve adalet sadece iktidarın devamını sağlayacak ama insanların vicdanını rahatsız edecek olan ve imtiyazlılar için yasa tarafından garanti altına alınmış ayrıcalıklardır. Orwell, baskıcı yönetim ve iktidarları eleştirdiği Hayvan Çiftliği (1945 [200o]) romanında da iktidar eliyle oluşturulan ve yanlış

Adres

İstanbul Medeniyet Üniversitesi, Eğitim Bilimleri Fakültesi, Türkçe ve Sosyal Bilimler Eğitimi Bölümü, Türkçe Eğitimi ABD Cevizli Kampüsü, Kartal-İstanbul/TÜRKIYE e-posta: editor@rumelide.com
Address

Istanbul Medeniyet University, Faculty of Education Sciences,

Turkish and Social Scinces Education, Turkish Language Teaching

Education, Cevizli Campus, Kartal-İstanbul /TURKEY

e-mail: editor@rumelide.com 
olduğu halde doğru bir vicdani ve ahlaki sistem kurduğu saviyla hareket eden güçleri eleştirmiştir. Herkesten "daha eşit” olan domuz grubu tıpkı Nietzsche'nin köle ahlakına uygun şekilde davranarak kendi varoluşunu efendinin var oluşu üzerine kurar. Vicdan rahatlı̆̆ ile kurdukları sistem ise tıpkı kendilerinden önce gelen güç istenci gibi ötekini köleleştirme üzerine kuruludur.

Bireysellik ile bağlantılı olan ve vicdani sistemin akıl ya da sezgi ile kurulduğunu savunan görüşler, vicdanı güç istencinin eline teslim etmeyi öneren görüşlere şiddetle karşı çıacaktır. Rönesans ve Reform sonrası ve Aydınlanma Çağı'nın etkisiyle birlikte bireysel olanın ön plana çıkması, Tanrısal ya da onun yansıması olarak herhangi bir iktidar gücüyle olsun, herhangi bir vicdani sistemin insana empoze edilmesi gerektiği görüşüne muhalifliği doğurur. İnsanın bireysel kimliğinin önemi, onun kendi vicdani sistemini kurmadaki asıl fail olması gerektiği görüşünü de getirmiştir. Bu noktada, Hegel'in bireyin vicdanın "hakikat ve iyiliğin nihai yargıcı olduğu” görüşü (Cevizci, 2015, s.761) vicdani işleyişte bireyselliğe önem kazandırmıştır. Fakat Hegel, toplumsal olarak dayatılan bir vicdani sisteme her ne kadar karşıysa insanların toplumun birer parçaları olduklarını unutarak hareket ettikleri bir vicdani sisteme de o kadar karşıdır. Ona göre, Aydınlanmayla birlikte "insanlar, kendi kimliklerini akıl olarak belirleyip, evrensel düşünce özgürlüğüne sahip olduklarını görmüş” (Cevizci, 2015, s.761) olsalar da tamamen bağımsız olduklarını düşünen bireyler aslında sosyal varlıklar olarak toplumun bir parçası olduklarını unutmamalıdırlar.

Bu bağlamda, Hegel için ne toplumsal kuralları bireylerin özgür iradeleri ve seçimleri olmadan uygulamak ne de sadece bireylerin kişisel vicdani sistemlerini kullanmaları doğru değildir. Ona göre, "nesnel dünya rasyonel olarak düzenlenmezse, kendi vicdanlarına göre eylemde bulunan bireylerin hukuk ve ahlakla çatışmaya düşmeleri kaçınılmaz olur” (Cevizci, 2015, s.762). Böyle bir düzen ise mevcut sistem ile bireylerin çatışması anlamına gelecektir. Çözüm, toplumun rasyonel bir şekilde düzenlenmesi, bireylerin kendi özgür iradeleri ve vicdanları ile eylemeyi seçmelerinin sağlanması ve böylece toplumsal düzenin vicdan sistemi ile bireylerin vicdan sistemlerinin örtüşmesi olacaktır. Hegel'in oldukça ideal görünen bu görüşü günümüzde neredeyse Platon'un Devlet'i kadar ütopik görünmektedir. Nitekim, toplumsal ya da güç düzeni ile bireylerin vicdani sistemlerinin çatışması olarak tanımlayabileceğimiz vicdani ret, bugün birçok toplumda birçok konuda söz konusu olmaktadır. Bireyin din, düşünce ve vicdan özgürlüğü ile hareket ederek, vatandaşlı̆̆ının ya da mesleğinin gerektirdiği eylemlere karşı vicdani karşı tavır geliştirmesi olarak vicdani ret, bireyin tercihlerinin dışsal yasalara karşı durmasıdır. Burada iki temel ilke birbirine karşı durur: "Ahlaki bütünlük ve vicdan ilişkisi” ile "kişinin kendiliği ve vicdan ilişkisi”" (Çelik, 2018, s.100).

Günümüzde en çok tartışılan vicdani ret vakaları, dini ya da etik öğretileri doğrultusunda hareket etmek isteyen bir doktorun kürtaj ya da ötenazi yapmayı reddetmesi ve savaşa karşı olan bir bireyin askerlik yapmak istememesidir. Vicdani ret savunucuları argümanlarını özellikle İnsan Hakları Evrensel Bildirgesinin 18. Maddesine dayandırırlar. Bu maddeye göre, "Herkesin düşünce, vicdan ve din özgürlüğü vardır” ve bu nedenle ahlaki kararları içeren durumlarda ya da bir başka deyişle kişinin vicdanını rahatsız edecek durumlarda kişisel haklar söz konusudur. Strohm'a göre (2011) bu basit bir şekilde herkesin kendi vicdanına göre davranacă̆ anlamına gelmemelidir; buradaki vurgu içsel inanç meselelerine gönderme yapar. Yani askerlik yapmak ya da yapmamak farklı kişiler tarafından farklı şekillerde gerekçelendirilebilir; fakat savaş kanunları ya da savaş suçu olarak belirlenmiş eylemleri gerçekleştirip bunun vicdani seçim olduğunu söylemek doğru olmayacaktır. Çünkü burada asıl çetrefilli konu gündeme gelir: Kişinin kendi vicdanına göre "eylemde bulunma" ya da "eylemde bulunmama" özgürlüğü... Bu özgürlük üzerine derin ahlaki ve politik tartışmalar vardır. Çünkü felsefi olarak vicdan özgürlüğü ahlaki ve dini görüşlerde çoğulculuğa müsaade edecek bireysel bir kavram

\footnotetext{
\begin{tabular}{r|l} 
Adres & $\begin{array}{l}\text { Address } \\
\text { İstanbul Medeniyet Üniversitesi, Eğitim Bilimleri Fakültesi, Türkçe }\end{array}$ \\
İstanbul Medeniyet University, Faculty of Education Sciences,
\end{tabular} ve Sosyal Bilimler Eğitimi Bölümü, Türkçe Eğitimi ABD Cevizli $\quad$ Turkish and Social Scinces Education, Turkish Language Teaching Kampüsü, Kartal-İstanbul/TÜRKIYE Education, Cevizli Campus, Kartal-İstanbul /TURKEY e-posta: editor@rumelide.com $\mid$ e-mail: editor@rumelide.com
} 
olarak anlaşılmaktadır (Strohm, 2011, s.90) ve bu sıklıkla tehlikeli sonuçlar doğurur. Bu noktada, vicdani sistemin işleyişinde üst akılın işlevine geri dönersek, vicdani reddin bir üst akla karşı duran vicdani seçimler olabileceğini ve bu nedenle üst akıl ile belirlenen vicdani doğruların da sıklıkla tartışmaya ve çoğu zaman da eleştiriye açık konular olduğunu söyleyebiliriz.

Doris Lessing’in günümüzden binlerce yll sonraki distopik bir dünyayı anlattı̆̆ı Mara ile Dann (1999 [2001]) romanında askerlikten çok daha farklı bir konuda-üreme konusunda-üst aklın getirdiği pratikler ve bu pratiklere karşı bir eleştiri ortaya konulur. Buz ve ateş çağlarından geçen dünyada Güney’in nüfusu kuraklık ve kitlık ile oldukça azalmış olduğundan köleleştirilen kadınlar üzerinden yönetim bir tür üreme programı geliştirir. Üreme araçları olarak kullanılan kadınlardan biri olan Mara, insan soyunun devam etmesi olarak sunulan verili ahlaki prensibe pratikte karşı çıkacak ve vicdani ret talep edecek durumda olmasa da pasif bir direniş olarak bebeğini kendi çabasıyla düşürür. Bebeğin doğsa bile zorlu iklim şartlarına dayanamadan öleceği gerekçesi üzerinden hareket eden Mara, bu şekilde iktidarın doğrularına karşı çıarak kendi bireysel vicdani sistemini işletmiş olur. Bu durumda Mara, Hobbes, Spinoza ve Locke gibi düşünürlerin devletin gerektiğinde toplumsal düzeni korumak için her ne kadar vatandaşların vicdani rahatsızlıklarına neden olsa da belirli pratikleri uygulama gücüne sahip olduğu görüşüne karşı duran bir karakterdir. Sonuçta, kendisine dayatılan vicdani sistemi takip ettiği için değil ona karşı geldiği için vicdanı rahattır.

Vicdani sistemin oluşumunda akıl, duygu ya da sezgi, ve üst akıl olmak üzere üç etmenden bahsettik. $\mathrm{Bu}$ üç etmenin taraftarları ve karşıtları şüphesiz en iyi vicdani sistemin nasıl kurulacağını bulma kaygısıyla kendi akıl yürütmelerini gerçekleştirmiştir. Bununla birlikte kimi düşünürler, ki bunlara sıradan insanları da eklemek gerekir, insanın vicdani sistemini kurarken sadece akıl ya da sezgisi ile değil bu ikisinin gerektiği yerde birlikte çalıştıkları bir tür vicdani sistemi önerir.

\section{2. Çoğulcu bir vicdani sistem}

Vicdan kelimesinin Latince karşıllğındaki "con scientia” yani "bilerek (with knowing)" eylemek sıklıkla vicdanın zihinden ayrı bir kuvve olmadığı fikriyle birlikte düşünülür. Fakat buradaki "bilmek" hem akılla hem de sezgiyle bilmeye bir işaret midir? Öz-düşünümsel yani kendi üzerine düşünen bir sistem olan vicdani sistem hem aklı hem de sezgiyi birlikte işletemez mi? Sidney Callahan, vicdanın kişisel, öz farkındalığı olan ve akıl, duygu ve de niyeti içinde barındıran bir aktivite olduğunu söyler (Spohn, 200o'de). Bu durumda akıl, sezgi, duygu ya da niyet vicdanın doğru bir şekilde işlemesi için tek başlarına yeterli değillerdir. Spohn'a göre, ahlaki bir karara varmak için akıl duyguyu eğitir, duygu akla yol gösterir ve böylece ahlaki bir karara varılır. Vicdani sistemde "bir düşüncenin sağlamasını yapmak"tan bahseden Spohn (2000, s.123) bu sağlamanın hem akıl hem de duygu ile yapılması gerektiğini gündeme getirir. Bu durumda Kant’n, katiline sığınmacısını teslim eden faili, eylemini akıl ile sınadığında yalan söylemediği için vicdani bir rahatlık hissedecekken, sezgi ya da duygu ile sınadığında muhtemelen aynı vicdani rahatlı̆̆a sahip olamayacaktır; her ne kadar Kant böyle olmaması gerektiği fikrini savunsa da... Vicdanı, akıl, sezgi ve duygunun bir dengesi olarak tanımlayan Callahan, şüphesiz çoğu vicdan teorisyenleri gibi bu karışımın tarifini tam olarak veremez. Fakat vicdanı hem akıl hem de sezgi ve duyguyla birlikte ele almayı gerektiren çoğulcu bir yaklaşım ya da bir başka deyişle vicdanın sesini dinleyerek davranmak bazı erdemler ile daha mümkün olabilir. Spohn bu erdemleri "metanet, sebat ve ahlaki iyiye tutkulu bir şekilde bağlllık" (2000, s.125) olarak tanımlar. Böylece, referans alınan erdemler doğrultusunda davranmak vicdani sistemin önemli bir temel üzerine kurulmasını sağlayacaktır.

Adres

İstanbul Medeniyet Üniversitesi, Eğitim Bilimleri Fakültesi, Türkce ve Sosyal Bilimler Eğitimi Bölümü, Türkçe Eğitimi ABD Cevizli Kampüsü, Kartal-İstanbul/TÜRKIYY e-posta: editor@rumelide.com
Address

Istanbul Medeniyet University, Faculty of Education Sciences,

Turkish and Social Scinces Education, Turkish Language Teaching

Education, Cevizli Campus, Kartal-İstanbul /TURKEY

e-mail: editor@rumelide.com 
Akılsal muhakeme ile kazanılacak bir sağduyu olarak vicdani sistemden bahseden Berg, vicdan üzerine yapılan sınıflandırmaları dörde ayırır (Berg, 2012): a) Genetik faktörler, çevre ve psikolojik güçler ile şekillenen duygusal bir tepki b) Bazılarının Tanrının sesi olarak düşündüğü bir tür doğal kuvve c) Basit bir şekilde akılla açıklanamayacak bir sezgi d) Ben ve diğerleri ne yapmalı ya da ne yapmamalı ile ilgili ahlaki fikir. Bu dört sınıflandırmanın tek başına vicdani sistemi açıklamadaki rolü Berg'e göre yetersizdir. Vicdanın bir tür duygusal tepkiye ya da "Tanrı'nın sesine indirgenmesi” bireysellikle ilgili problemler yaratır. Bir tür içsezi ya da sezgi olduğunu söylemek de aklı ve normları dışarıda bırakarak çeşitli vicdan dışı vakalara yol açabilir. Sadece içsezi üzerine kurulmuş bir vicdani sistemin işlerliği hemen tüm ırkçı ya da dini soykırımlara bir tür olumlama olurdu.

Vicdanın bu dört sınıflandırmasının her birinin tek başına yeterli olduğu görüşüne karşın Berg de Callahan gibi çoğulcu bir yaklaşım taraftarıdır. Bu bakımdan vicdanı "aklın içsel yankısı" (Berg, 2012) olarak adlandırarak temelde akıl ve sezgiyi bağdaştıran bir vicdani sistem önerir. Bu açıdan vicdan, bir seçim için iyiye ve gelişmeye doğru bir şekilde yönelten davranış ile akletmektir. Burada seçim ile ahlaki norm arasında bağdaşım (harmony) ya da bağdaşmazlık (disharmony) söz konusu olabilir. Spohn gibi Berg de bu uyumun sağlanmasını eylemin, bağlı olduğu erdem ile uyuşmasıyla açıklar. Vicdanın bazı referans noktaları vardır ve bunlar da erdemlerdir. Eğitim ve ahlaki öğretiler ile, referans noktaları olan bu erdemlerin gelişeceği unutulmamalıdır.

Berg'e göre hakiki vicdanı basit bir ahlaki fikirden ayıran şey sağgörü ya da ihtiyatlllık erdemidir, ki bu erdem kardinal erdemler arasında sayılır. Fakat bu sağgörü bireyi nesnel normlardan uzaklaştırmamalı, onu öznelliğe yöneltmemelidir. İhtiyatlı bir birey vicdani yargısının yanılabileceğini bilmeli, bu nedenle nesnel ahlaki normlara ve kanıtlanmış ahlaki kılavuzlara başvurmalıdır. Vicdani sistemin işeyişinde belirli bir vicdani yargı ile bir fikri benimsemek arasındaki farkı bulmak zordur. Öznelliğin bizi götürdüğü "bence” fikri, vicdani kararlar için yetersiz kalacaktır. Çünkü benceler, çoğunlukla akıl yürütmeden ziyade duygusal tepkilerin bir sonucu olarak ortaya çıkarlar. Oysa vicdani yargılar hiçbir zaman nesnellik ve ahlaki prensiplerin sürekliliği ile tanımlanmaktan uzaklaştırılmamalıdır.

\section{Vicdan ve eylem}

\section{3.a. Eylemden önce ve eylemden sonra işleyen vicdani sistem}

Vicdanın harekete geçmesiyle ilintili olan ve bizi eyleme götürecek iki önemli kuvveden akıl ve sezginin vicdani sistemin işleyişine nasıl etki ettiklerini ya da etmesi gerektiğini kuramsallaştıran düşünürler, vicdani sistemin eylemden sonra da işlemekte olduğunu unutmayarak vicdanın özellikle eylem ya da eylemsizlikle (eylemsizlik de burada bir tür eylem ve karar olarak ele alınmalıdır; çünkü vicdani sistemin işleyişi bir şey yapmak kadar yapmamakla da bağlantılıdır) ilişkisini göz ardı etmemelidir.

Vicdanın inşa edilmesi derin bir şekilde ahlaki hakikati aramaya karar vermekle başlar. Buradaki süreç doğru ve yanlış nedir, ne yapmalıyım ve ne yapmamalıyım soruları üzerinden gider ve ahlaki olarak kesinliğe ulaşıncaya kadar devam eder. Vicdanın sesi doğruluk, dürüstlük ve samimiyet temeli üzerine sağlamca oturtulmalı ve böylece doğru eyleme yönelinmelidir (Berg, 2012). Fakat burada şu soru ortaya çıkar: Eylemden önce işleyen vicdani sisteme eylemden sonra ne olur? Aslında vicdan süregiden bir öz-inşa, içe-bakış, öz-değerlendirme süreci olduğu için eylemden sonra da hem akıl hem sezgi hem de birey dışındaki ahlaki normlarla, ortaya konulan eylem vicdani olarak sorgulanmaya devam eder.

Adres

İstanbul Medeniyet Üniversitesi, Eğitim Bilimleri Fakültesi, Türkce ve Sosyal Bilimler Eğitimi Bölümü, Türkçe Eğitimi ABD Cevizli Kampüsü, Kartal-İstanbul/TÜRKIYE e-posta: editor@rumelide.com
Address

İstanbul Medeniyet University, Faculty of Education Sciences,

Turkish and Social Scinces Education, Turkish Language Teaching

Education, Cevizli Campus, Kartal-İstanbul /TURKEY

e-mail: editor@rumelide.com 
Timothy O'Connell vicdanı, kapasite, süreç ve hüküm olarak ele alır ve insanların doğruyu yanlıştan ayırma kapasiteleri olduğunu belirtir (Spohn, 2000'de). Doğruyu yanlıştan ayırıp vicdanına göre eylemek amacında olan birey pratik süreçte doğru olana uygun olarak hareket etmiş olur. Fakat vicdani sorgulama eylemden sonra da devam eder. Eylemin sonucunda vicdani bir rahatlama mı yoksa vicdan azabı mı yaşanacağı eylemin vicdani sağlamasının yapılmasına bağlıdır. Akıl ve sezginin süzgecinden geçen vicdani karar gibi eylem de gerçekleştirildikten sonra aynı süreçleri izlemek zorundadir.

Vicdanı meydana getiren unsurların iyilik ve hakikate ulaşma arzusu olduğundan bahseden Berg, vicdanın sesini dinleyerek onu test etmenin iki önemli sağlama ile yapılması gerektiğini söyler. Öncelikle ortaya çıkan kararın ve eylemin "bence" fikriyle gerçekleştirilen bir ahlaki yargı ve eylem olmaması gerekir; ikincisi ise şüphenin ortadan kaldırıldığı net ve emin bir karar ve eylem olmalıdır. Eğer vicdani soruşturma bu iki sorgulamaya istenilen cevabı verebiliyorsa ortaya konulan eylemden dolayı vicdani bir rahatlık duyulabilir. Vicdanın bir tür içebakış, öz-sorgulama, öz-değerlendirme olması, onun eylemden sonra da devam etmesini gerektirir. İnsanın kendi davranışlarının farkındalığına sahip olması, onun öz-denetleme ile eylemden önceki sorgulamasını eylemden sonra da bir tür sağlamayla devam ettirmesine neden olur. Buradaki işleyiş benliğin ikiye ayrılıp, var olan durumda benliğin bir yarısının diğer yarısı tarafından sorguya çekilip değerlendirilmesidir (Sorabji, 2014, s.12). Bu sorgu, antik Yunan tragedyalarından Euripides'in Orestes adlı oyununda anne-katline karşı başkahramanın yaşadığı benlik bölünmesinde kendini açıça göstermektedir. Orestes tragedyasında benlik bölünmesi yaşayan Orestes, vicdani sorgulama üzerine kurulu iki "kişilik" arasında gidip gelmektedir: Ahlaken yanılmış ben'in bilgisini paylaşan kişilik ve "hatalı, kusurlu olduğunun bilgisine sahip olup onu saklayan” kişilik (Çelik, 2018, s.80). Yanılmışlığın bilgisini paylaşmak kişiyi vicdani bir sorgulama yoluna iterken ahlaki kusuru bilip, saklamak-tıpkı Orestes gibi-kişiyi vicdani bir rahatsızlığa sürükleyecektir. Eylemden sonraki vicdani sorgu uzun ya da kısa sürebilir. Şüpheler ne kadar fazlaysa iç sorgulama o kadar uzun sürecek, sonucunda da ya vicdan rahatlığına ya da vicdan azabına dönüşecektir. Bu tür bir öz-sorgulamada benliğin ikiye ayrılmasının dışında, hayali bir tanık ya da aşkın bir gözlemcinin-Tanrı gibi-önünde vicdani bir sorgulama yapılıyor hissi de doğabilir. Böyle bir vicdani sorgulamada hipotetik bir mahkeme, sorgu ve hüküm söz konusudur.

Bu tür bir öz-denetlemenin, içsel bir mahkeme önünde hesap vermenin edebiyattaki en güzel örneklerinden biri şüphesiz Shakespeare'in Macbeth'idir. Bilindiği gibi, Glamis Baronu olan Macbeth, karşılaştığı üç cadının kehanetine uyarak, babası gibi yakın gördüğü İskoçya kralı Duncan’ı öldürüp kraliyet tahtına geçme arzusu içine girer. "Karanlık ve derin arzularımın gün yüzüne çlkmasına izin verme" (Macbeth, 1.4. 53) diye aydınlığa yalvarsa da Macbeth hırsına yenik düsser ve karısı Lady Macbeth'in de yönlendirmeleriyle Duncan'ı dramatik bir şekilde katleder. Macbeth ve Lady Macbeth arasındaki vicdani sorgulama özellikle eylemden önce ve eylemden sonraki öz-denetleme açısından farklıllk gösterir. Cinayetten yani eylemden önce Macbeth daha yoğun bir vicdani sorgulama yaparken Lady Macbeth daha kesin ve kararlı görünür. Doğrudan eyleme yönelerek bu cinayetin gerçekleştirilmesi için elinden geleni yapar. Fakat Lady Macbeth kocasıyla birlikte gerçekleştirdiği cinayetlerin vicdani ağırlığını Macbeth gibi kaldıramaz ve vicdan azabından çöker. Oyunun en ünlü sahnelerinden Lady Macbeth’in gerçekleştirdiği eylemlerin vicdani ağırlığı altında bilinci tam yerinde olmadan gezip ellerine bulaşmış hayali kan izlerini çıkarmaya çalıştığı sahne, vicdani sorgulamanın ne kadar ağır olabileceğinin unutulmaz bir sunumudur. Lady Macbeth histerik bir şekilde elinde kan izleri olduğu ve bunların çıkmadığı fikriyle delirir ve sonunda ölür. Oyunda kesin olarak belirtilmese de delirmesi Lady Macbeth’in muhtemel olarak intihar ettiği fikrini akıllara getirir.

Adres

İstanbul Medeniyet Üniversitesi, Eğitim Bilimleri Fakültesi, Türkce ve Sosyal Bilimler Eğitimi Bölümü, Türkçe Eğitimi ABD Cevizli Kampüsü, Kartal-İstanbul/TÜRKIYE e-posta: editor@rumelide.com
Address

Istanbul Medeniyet University, Faculty of Education Sciences,

Turkish and Social Scinces Education, Turkish Language Teaching

Education, Cevizli Campus, Kartal-İstanbul /TURKEY

e-mail: editor@rumelide.com 
Bu durumda eylemden önce Lady Macbeth daha kararlı ve vicdani olarak rahat görünürken eylemden sonraki vicdani sorgulaması onu delirmeye ve ölüme götürür. Oysa eylemden önce vicdani muhakemesi ve endişeleri daha fazla olan Macbeth'in kralı öldürdükten sonra pek fazla vicdani sorgulamaya gitmediği görülür. Macbeth iktidar istenciyle daha fazla kişiye ihanet eder ve daha fazlasını öldürmekten çekinmez. Öldürdüğü bir başka soylu Banquo'nun hayaletinin sarayda verilen bir yemek esnasında gelip artık İskoçya Kralı olan Macbeth'in koltuğuna oturması ise Macbeth'in ancak bilinçdışı olarak işleyen vicdani sorgulamasının göstergesidir. Belki de Macbeth, olanlar üzerine yapacağı vicdani bir iç sorgulamada karısı gibi delirmekten korktuğu için vicdani sorgulamasını görmezden gelir ve bilinçdışına iter.

Vicdanın büyük oranda içsel olan yapısı bizim ahlaki olarak kendi hakkımızdaki yansımalarımızı değerlendirmemizi sağlar. Bu öz-denetleme kimi zaman bilincin aktif olduğu durumda kimi zaman ise bilinçaltı ve bilinçdışı olarak ilerler. Vicdani sorgulamanın hafıza ile bağlantılı olması eylemlerin hatırlanması ve yeniden denetime tabi tutulmasını sağlar. Bu nedenle bazen vicdan rahatlığıyla gerçekleştirdiğimiz eylemleri daha sonra tekrar sorgulayarak vicdani bir rahatsızlığa düşebiliriz. $\mathrm{Bu}$ durumda artık duygudan ziyade akılsal süreçlerin etkili olduğu açıktır. Lady Macbeth hırs, arzu, kıskançlık gibi duygularıyla hareket ederken ona kendini hissettirmeyen vicdan azabı zihinsel değerlendirme işin içine girdiği zaman katlanılamayacak bir boyuta ulaşır. Bu nedenledir ki, vicdan üzerine düşünen felsefeciler vicdani sorgulamada eylemden önceki sürece eylemden sonrakinden daha çok önem verirler ve vicdani sistemden bahsederken daha çok eylem öncesi karar süreci üzerinde dururlar. Bunun en önemli nedeni şudur ki, eylemler geri çevrilemez, en iyi ihtimal ile telafi yoluna gidilebilir. Bu telafinin ise ne kadar vicdani rahatlama sağlayacağı sorunsaldır.

\section{3.b. Eylem ya da eylemsizlikten sonra iç muhasebe ile ortaya çıan duygular}

Vicdani sistem akıl, sezgi, duygular ya da dışsal normlarla işledikten ve bir eylem ya da eylemsizlik ile sonuçlandıktan sonra akılsal süreç eylemin sorgulanmasına devam eder ve ortaya artık duygu ve hisler çıar. Vicdani sistem işlerken akıl yargılar, kalp hisseder. Bu nedenle eylemden sonra daha çok vicdani huzursuzluk (eylemin ahlaki olarak doğruluğundan emin olamama), vicdan rahatlı̆̆ (eylemin doğruluğundan emin olma), vicdan sızlaması (katlanılabilir bir vicdani rahatsızlık) ya da vicdan azabı (yanlış eylemde bulunmanın ağırlığı altında ezilme) olarak ifade edilen duygular ortaya çıkar. Vicdan üzerinde akıldan çok duygunun hâkim olduğu süreç de bu alsa gerek. Olan olmuştur ve Macbeth’in sözleriyle, yaşamdan geriye sadece "ses ve öfke" (Macbeth, 5.5. 26-27) kalmıştır.

Vicdani sorgulama sonucu ortaya çıkan duygular genellikle olumsuz duygular ile ilişkilendirilir (Arendt, 1971); suçluluk, pişmanlık, azap, utanç gibi... Kendinden memnun vicdani hislerin olumsuz hislere oranla daha kısa süreli ve daha az çetrefilli vicdani sorgulamalar sonucu ortaya çıkması büyük oranda söz konusu eylemde birbiriyle çatışan kutupların az olmasından kaynaklanır. Vicdani kararın birbiriyle en çok çatıştığı durum kişide haz ve sorumluluk ilkelerinin savaşmasıyla ortaya çıkar. "Ne yapmalıyım" ile "ne yapmak istiyorum"un içsel sorgulamalarımızda sıklıkla karşı karşıya geldiğine tanık olmuşuzdur. Örneğin acıma duygumuz bizi dilenen bir çocuğa para vermeye ikna eder fakat ahlaki sorumluluk hissimiz bunu yaptığımız sürece o çocuğun dilendirileceğini hatırlatarak bizi engeller. Burada ilk akla gelen parayı verip yaptı̆̆ımız "iyilik"in hazzına varmaktır; oysa sorumluk tarafını tercih edersek arkamızdan yalvarmaya devam eden bir sesin bizi bu hazdan mahrum bırakacağını biliriz.

Adres

İstanbul Medeniyet Üniversitesi, Eğitim Bilimleri Fakültesi, Türkce ve Sosyal Bilimler Eğitimi Bölümü, Türkçe Eğitimi ABD Cevizli Kampüsü, Kartal-İstanbul/TÜRKIYYE e-posta: editor@rumelide.com
Address

İstanbul Medeniyet University, Faculty of Education Sciences,

Turkish and Social Scinces Education, Turkish Language Teaching

Education, Cevizli Campus, Kartal-İstanbul /TURKEY

e-mail: editor@rumelide.com 
Yapmamız gereken ve yapmak istediğimizin çatıştığı durumlar günlük, sıradan durumlarla sinırlı değildir. Haz ve sorumluluk ilkesinin yıllarca çatıştığı ve sonuçta çok tartışılan etik bir konuya-ötenazi gibi-varan vakalar belki de bunun en uç örneğidir. Paris'te yaşayan Türk anne Meral Tüzün'ün on yedi yll boyunca verdiği vicdani muhasebeyi anlatan Sevginin Son Kanıtı (2011) adlı özyaşamöyküsünde böyle bir iç muhasebeyi ayrıntısıyla görmek mümkün. Bir annenin bitkisel yaşamda olsa da çocuğunun yaşaması ve yanında olmasından aldığı küçük haz, onu aslında bu hayata mahkûm etmemesi, kendi küçük mutluluğu için bitkisel hayatta evladının çektiği acılara izin vermemesi gerektiği fikri ve bu noktada evladına karşı sorumluluğuyla on yedi yıl boyunca çatışır. Türk anne bu uzun süreden sonra, sonucunda oldukça acı duyacağı ama yapması gerektiğine kanaat getirdiği ötenazi kararını alır. Haz ve sorumluluğun çatıştı̆̆ı, vicdani muhasebenin en çetrefilli şekilde yapıldığı sayılı örneklerin bir temsilcisidir bu vaka. Eylemin sonucundaki duyguların vicdani sorgulamanın olumsuz sonuçlarından olmadığını annenin demeçlerinden öğreniyoruz. Annenin eylemin sonunda suçluluk ve pişmanlık gibi bir vicdani hisse kapılmadığını okuyoruz; bu olumsuz duygular aslında tam tersi eylemsizlik durumunda, yani ötenazi kararını almadan önce, onunla birlikteydi. Fakat vicdani sorgulamayla birlikte eylemin sonucundaki duyguyu tanımlamak da bu vaka için oldukça zor olsa gerek. "Yapmam gerekeni yaptım” ama "sonuçta çok üzüldüm” fikrine karşılık gelen duygu nasıl adlandırılırsa o...

Vicdani muhakemede, içimizde sıklıkla farklı seslerin zihnimize müdahale ettiğini tecrübe ederiz. Kamuoyu önüne çıkarılmış bir tartışma var gibidir zihinde. Bu sesler kimi zaman aşkın bir varlık -din, Tanrı-, kimi zaman ise hayran olunan bir kanaat önderidir -dini önderler (özellikle peygamberler), ideolojik liderler, anne/ baba imgesi gibi. Bu kişiler ahlaki ya da duygusal olarak nötr bir gözlemci değildir; fakat kişinin onay ya da ret duygusunu kontrol ederler (Raphael, 2007). Bu tür bir içsel mahkemeden gelen sesler özellikle eylem ya da eylemsizlik durumundan sonra daha yüksek çımaya başlar. Peki bu duygular ne işe yarar, bir işlevi var mıdır? Onay ya da ret olsun vicdani muhakeme sonucu ortaya çıkan duygular psikolojik olarak kişinin kendini ödüllendirmesi ya da cezalandırması ile ilintilidir. Vicdani rahatlık bir tür psikolojik ödül olarak işlerken vicdan azabı kişinin kendini mahkûm ettiği bir öz-cezalandırma haline gelir.

Vicdan kişinin mahrem ahlakı ile bağlantılı olduğu için duygular da çoğu zaman mahrem kalır ve dışa vurulmadığı zaman daha da şiddetli yaşanır. Duygularımızı aslında bir şekilde vicdanın kurallarına uyarlamaya çalışırız ve buna göre duygulanımlar geliştiririz. Kant'ın "insandaki içsel mahkemenin idrakı" (Kant, 1797 [1991], s.189) olarak vicdan tanımı, içsel sorgulamanın her daim devam ettiğini hatırlatır. Bu nedenledir ki, dava ya ödül ya da ceza ile sonuçlanacaktır. İçsel mahkemeden suçsuz çıkan vicdani sorgulama bir tür rahatlama ile ödüllendirilecek, suçlu olduğuna kanaat getirilen ise cezalandırılacaktır ve en ağır ceza "cezasını çekti” diyemeyeceğimiz bir öz-cezalandırmadır. Bu tür bir öz-cezalandırma oldukça detaylı ve etkileyici bir şekilde Dostoyevski’nin Suç ve Ceza'sında (1866 [1995]) anlatılır. Kitabın ismindeki ceza, başkarakter Raskolnikov'un işlediği suçtan dolayı kurtulamadığı vicdan azabıdır.

Yoksul bir genç olan Raskolnikov hukuk öğrenimini bırakmak zorunda kalmıştır, sefalet içinde yaşar. Öldürmeye karar verdiği yaşlı kadın ise insanların maddi zorluklarından faydalanan kötü bir tefecidir. Raskolnikov bu kadını aniden ya da yanlışlıkla öldürmez; eyleme geçmeden önce bu eylem üzerine düşünür; eylemin vicdani bir sorgulamasını yaparak kadını öldürmeye karar verir. Bu cinayetin gerekçeleri Raskolnikov'un zihninde mantıksal bir zemine oturmuştur. Öncelikle kadın kötü bir insandır ve onun ölümü dünyayı kötücül bir failden kurtaracaktır. Bunun yanı sıra kadından aldıklarıyla maddi problemlerini çözecek, okuluna devam edecek ve topluma yararlı bir insan olacaktır. Raskolnikov ahlaki gördüğü bu amaçlar için ahlak dışı bir eylemde-cinayet-bulunacaktır;

\footnotetext{
\begin{tabular}{r|l} 
Adres & $\begin{array}{l}\text { Address } \\
\text { İstanbul Medeniyet Üniversitesi, Eğitim Bilimleri Fakültesi, Türkçe }\end{array}$ \\
İstanbul Medeniyet University, Faculty of Education Sciences,
\end{tabular} ve Sosyal Bilimler Eğitimi Bölümü, Türkçe Eğitimi ABD Cevizli Turkish and Social Scinces Education, Turkish Language Teaching Kampüsü, Kartal-İstanbul/TÜRKIYE Education, Cevizli Campus, Kartal-İstanbul /TURKEY e-posta: editor@rumelide.com $\mid$ e-mail: editor@rumelide.com
} 
bu nedenle eyleminin kabul edilebilir olduğuna karar verir ve yaptığı planların ardından kadını baltayla öldürür. Planda olmayan, cinayet sırasında kadının üvey kız kardeşini de olayın üzerine gelmesinden dolayı öldürmek zorunda kalmasıdır.

Eylemden önce cinayetini zihninde meşrulaştıran Raskolnikov, eylemden sonra derin bir pişmanlık ve vicdan azabı yaşar; neredeyse Lady Macbeth gibi çıldıracaktır. Baygınlık nöbetleri geçirir, günlerce hasta yatar. Tüm bu fizyolojik olaylar aslında Raskolnikov'un öz-cezalandırmasının dışavurumudur. Kadının evine geri dönmesi belki cinayeti geri çevirmek için hayali bir umut belki de yakalanıp cezasını çekmek için bir tür bilinçaltı güdülenmedir. Nitekim Raskolnikov cinayeti işledikten sonra hiç de işlemeden önceki akıl yürütmelerini haklı bulmaz ve sonunda yaşadığı vicdani muhasebe ve hissettiği vicdan azabı ona suçunu itiraf ettirir. Dostoyevski, Raskolnikov'un ceza olarak Sibirya'da geçirmek zorunda olduğu sürgünün ne kadar vicdanını rahatlatacağı fikrini de romanda sorunsallaştırır. Çünkü dışsal bir ceza, vicdan azabı olarak kendini gösteren öz-cezalandırmayı telafi etmez. Raskolnikov'un asıl cezası, vicdanının sürekli onu rahatsız etmesi, pişmanlık, korku, azap duygularıyla ona asla rahat vermemesidir.

Bir eylemin ardından vicdanla ilgili olumlu ya da olumsuz duygular ancak vicdani sistemin işlediği kişilerde ortaya çıkar. Bu sistemin zaten hiç kurulmamış olduğu ya da artık işlemediği kişiler için herhangi bir vicdani rahatlık ya da vicdan azabından bahsetmek mümkün değildir. Örneğin psikopatlar için vicdani sistemin varlığından bahsedemeyiz. Bu kişilerde vicdani süreç işlemediği için onların vicdansız davrandığını söylemek de uygun değildir. Bir katil iç muhasebe yapıp vicdan azabı çekebilir ya da vicdanını rahatlatabilir oysa psikopat için bu sistem zaten yoktur. Freud psikozun "benlik ile dış dünya arasındaki bir çatışmaya karşılık geldiğini” söyler (Freud, 1926 [1999], s.200). Bu tür bir çatışma ise gerçekliğin yitirilmesi ile sonuçlanır. İdin egemenliğindeki psikozda vicdan, yani Freud'un süperego olarak tanımladığı mekanizma, işlemez.

Psikozda gerçekliğin yitirilmesi zorunludur ve gerçeklik psikoz yaşayan kişi tarafından yeniden inşa edilir; gerçekliği yadsıyan psikoz onun yerini doldurmaya çalışır (Freud, 1926 [1999], s.209). Bu nedenle, sıradan insanlardaki vicdani sistem işleyişi, yani akıl, sezgi, duygu ve dışsal normlarla kurulan işleyiş, psikoz yaşayan insanlarda sıradan insandaki gibi gözlenmez. Vicdani sistemde önemli bir etken olan şüphe psikozda işlemez, onun özelliği kesinliktir (Fink, 1999, s.84); bu nedenle psikotik, derin vicdani muhakemeye gitmez. Duygu ve düşüncelerin ağır şekilde bozulduğu zihin durumuna tekabül eden psikopatlarda vicdani rahatsızlıkların görülmemesinin nedeni onların doğru bir vicdani muhakeme yapamamalarından değil, zaten böyle bir sistemin onlarda hiç işlememesinden kaynaklanır ve suçluluk, pişmanlık, utanç gibi duygulanımları yaşamamalarıyla sonuçlanır. Robert Hare, Without Conscience: The Disturbing World of the Psychopaths Among Us (1999) adlı kitabında psikopatların vicdandan muaf olduklarından bahseder. Bu durumda herhangi bir suçludan oldukça farklıdırlar. Psikopatlar için "vicdansız olmak" gerçek anlamda "bir vicdana sahip olmamak" demektir, ki böyle bir durumun tahayyülü bile sıradan insanlar için oldukça zor ve korkutucu görünmektedir.

\section{Vicdan ve özgürlük}

Vicdanın sıklıkla, sonucunda ortaya çıkacak olumsuz duygular ile ilintilendirilerek kullanılması (örneğin vicdan yapmak, vicdan rahatlığından ziyade bir tür vicdani rahatsızlığa gönderme yapar) vicdani sistemin insanı kısıtlayan bir mekanizma olarak algılanmasına neden olur. Peki vicdan insanı, onun düşünce, duygu ve eylemlerini, ne derecede kısıtlar? Vicdanına göre eylemek insanda ne gibi sinırlamalara neden olur?

Adres

İstanbul Medeniyet Üniversitesi, Eğitim Bilimleri Fakültesi, Türkce ve Sosyal Bilimler Eğitimi Bölümü, Türkçe Eğitimi ABD Cevizli Kampüsü, Kartal-İstanbul/TÜRKIYE e-posta: editor@rumelide.com
Address

İstanbul Medeniyet University, Faculty of Education Sciences,

Turkish and Social Scinces Education, Turkish Language Teaching

Education, Cevizli Campus, Kartal-İstanbul /TURKEY

e-mail: editor@rumelide.com 
Ahlak felsefecileri sıklıkla doğru ve yanlışı tartışırken, doğru eyleme göre karar vermenin insana ne sağlayacağı hususunda görüş bildirirler. Aristoteles için kişiyi ahlaklı olmaya yönlendirecek erdemler ona aradığı mutluluğu sağlayacaktır. Fakat Aristoteles'e göre "yalnız erdemi bilmek yetmez, ona sahip olmak, onu yapmak da gerekir". Burada, vicdani sistemde referans noktaları olarak alınması gereken erdemler bağlamında düşünürsek, doğru bir vicdani sistemin sadece erdemi düşünmek, onu istemek, ona niyet etmekle değil, aynı zamanda onu gerçekleştirmekle ilintili olduğu unutulmamalıdır.

Kant, "vicdanına göre eyle" derken aklın, ahlaklı davranan insanlarda kendini vicdan olarak gösterdiğine vurgu yapar. Bu nedenle, aynı düsturu "akıl ile eyle" diye yazabiliriz. Kant felsefesinde akıl ile işleyen bir vicdan insanı özgürleştirecek, ona doğru olan yolu gösterecektir. Bu süreçte Kant'a göre, insan kendini özgürleştirmek için kendi çabasıyla ve özerklik ilkesiyle ilerlemelidir. Kant'ın özerklik ilkesi şunu gerektirir: "Seçimini öyle yap ki seçiminin ilkeleri aynı zamanda evrensel yasalara uygun olsun" (Kant, 1785 [2006], s.47). Fakat bu evrensel yasalar din, Tanrı, gelenek, kültürel norm, devlet gibi dişsal otoritelerle belirlenen yasalar değildir; kendi kendimize keşfedebileceğimiz (Kant, 1785 [2006], s.137), saf akıl ile test edilip karar verilecek ve her topluma her döneme uyacak yasalardır.

[Kant'ın] [b]ireyler üstü bir moral gerçekliği ifade edip tanımladığı dikkate alınırsa, vicdanı eyleme temel almanın biri ahlak yasasıyla, diğeri özgürlükle ilişkili ana boyutu olduğu söylenebilir. Çünkü tüm bireylerin üstünde ve ötesindeki bir ahlaki gerçeklik olarak vicdanı eyleme temel almak genel nitelikte olan bir yasayı istemek, ödev bilincine sahip olmak, ahlak yasasının peşinden koşmaktır. (Cevizci, 2015, s.732)

Kant, aklın rehberliğinde ilerleyen bu ahlak yasasını ve onunla bağlantılı olan vicdani sistemi özgürlüğe giden yol olarak tanımlar. İnsanı "homo numen" ve "homo fenomen" olarak tanımlayan Kant'a göre insan hem aklı hem de doğası ile var olan bir varlıktır. Bu durumda akıl ile ulaşılan ahlaki yanı, yani numen yönü, doğası ile bağlantılı olan fenomenal yönünü kontrolü altına almalıdır. İnsanın hazzı arzulayan bir varlık olduğunu söylemek yanlış olmaz. "Arzulayan yanımız Kant’a göre fenomenal, duyusal, dürtüsel yönümüzü temsil eder. Bunun karşısında ise pratik akıl ve aklın buyrukları vardır” (Ylldı, 2015, s.145). Yani insan hem arzulayan hem de düşünen bir varlık olarak arzuyu aklın rehberliğinde hareket ettirebilir ve böylece özgürlüğe ulaşacaktır.

Kant'a göre haz ve akıl arasındaki gerginlik daimidir. Fakat duygular ve haz ile hareket etmeye meyilli olan insan yine de seçim yapma konusunda bir bakıma özgürdür. Ona göre ancak duyusal içerikten ziyade akıl kişinin eylem ve maksimini belirlerse ve seçimlerine yön verirse özgürlük sağlanabilir. Bu durumda doğru işleyen bir ahlaki ya da vicdani sistem insanı kısıtlamanın tersine ona özgürlük sağlayacaktır. Bu noktada hazzın evrilmesinden de söz etmek gerekir. İnsanın her yönüyle evrilen bir varlık olduğunu düşünürsek Freud'un tanımladığı id'in hazlarından kurtulmak ve yerine daha yüce (sublime) hazlar koymak mümkündür. Vicdani haz da bu bağlamda ele alınmalıdır. Örneğin Doris Lessing’in Memoirs of a Survivor (1974 [1976]) adlı romanında bir gün tanımadığı bir adam tarafından evine getirilip bırakılan kimsesiz bir kız çocuğuna bakması beklenen bir kadın anlatılır. Kadının adamla ya da kızla hiçbir bağı yoktur; üstelik oldukça zor şartlarda, bir felaket sonucu dünya yokluğu ve kaosu yaşamaktadır. Kadının kızı kabul etmesi demek evinden göç etmesini bile gerektirebilecek bu kaosun içinde özgürlüğünü tamamen teslim etmesi anlamına gelecektir. Fakat kadın küçük Emily’i sorgusuz sualsiz yüce bir "sosyal bilinç ve şiddetli bir görev hissiyle" (Myles, 1991, s.13) kabul eder. Bununla birlikte kadının bu eyleminin nedeni görev hissinin çok üstünde olan vicdani bir hazdan kaynaklanır. e-posta: editor@rumelide.com 
Freudcu haz, rahat bir yaşam, sorumluluk hissinin olmadığı bir “özgürlük”ten bahsederken, buradaki haz sorumluluk hissiyle gelişmiş bir tür evrilmiş hazdır. Romandaki kadın, Judith Thomson'ın kürtaj savunuculuğu yapmak için örneklendirdiği, kendisine zorla bağlanmış bir kemancıyı dokuz ay yanında taşıması istenen kişinin adeta somut bir örneğidir. Thomson "A Defence of Abortion” (1971 [1986]) adlı makalesinde, bir sabah uyandığınızda kendinizi yanınızda bilinci kapalı bir kemancıyla dolaşım sisteminiz bağlı bir şekilde bulsanız ve dokuz ay boyunca kemancının yaşaması için bunu kabul etmeniz istense "bunu kabul etmek zorunda mısınız" diye sorar ve istenmeyen bir gebeliğin "zorunda" hissettirilmemesi gerektiğini haklı göstermek ister. Lessing’in karakteri adeta bu kemancıyı hemen kabul edecek bir kadındır. Nitekim romanın devamı sorgusuzca kabul ettiği Emily'e karşı gösterdiği özen ve iyi niyet ile sağlanan bir tür vicdani hazzı örnekler. Özgürlük, yüceltilmiş bir vicdani haz olarak tanimlanir.

Kant gibi Fichte de vicdanı özgürlük ile ilintilendirerek vicdan ile gelecek bir tür rahatlama ve özgürlük imkanından bahseder. Fichte'ye göre, ahlak yasası çerçevesinde davranmak insanı özgürlüğe yükseltecektir (Cevizci, 2015, s.732). Nietzsche ve Freud da vicdanın oluşumunda içgüdülerin bastırılması ve bununla birlikte dönüşüme uğrayan bir vicdani sistemden bahsederler; fakat onlara göre bu, Kant’ın özgürleştirici süreciyle aynı değildir. Freud'a göre içgüdülerin bastırılması ve insanın doğal yanından kopuşu vicdani sistemi kuracaktır. Burada vicdan, en küçük yapı olarak ailede en büyük yapı olarak ise toplum ve devlet eliyle oluşur. Genel anlamda toplumun sesi olan vicdan, bu durumda Kantçı bir özgürlük yaratmaz. Bu şekilde içselleştirilmiş vicdan, dışsal bir yasanın etkisiyle oluştuğu için insanı suçlu hissettirir. Nietzsche de Freud gibi insanın vicdani sistem ile kendini sınırlamasını onun suçlu hissetmesinin nedeni olarak görür (Nietzsche, 1887 [1967]).

Özgürlük bugün hala çeşitli kollarda süregiden bir tartışma... Bu noktada, insanın akıl ve sezgilerini kullanarak elde edeceği ve her daim gelişmeye açı bir vicdani sistemi belki de hürriyet kavramı ile tanımlamak daha doğru olacaktır. Hürriyetin, "insanın içgüdüye sahip olmadığı bilgisini ona vererek insanın hür olmasının yolu” (Erdoğdu, 2017, s.87) tanımından yola çıkarak, insanın hem vicdani haz duyacağı hem de akıl ve sezgileri doğrultusunda işlemesine izin vereceği vicdani sisteminin onu hür kılacağını söyleyebiliriz. "İnsan güdülerine dur dediği zaman yani hürriyet kavramıyla hareket ettiği zamanlarda diğer hassaları nefes almaya ve inkişaf etmeye başlar" (Erdoğdu, 2017, s.80). Bu nedenle salt güdüler ile hareket etmeyi bırakan insanın ancak bu şekilde vicdanı da nefes alacak ve kişi hürriyetini sağlayacaktır.

\section{Sonuç}

Her ne kadar vicdan tam olarak şudur diye tanımlayabildiğimiz bir kavram olmasa da ve tarih boyunca ilk çağ filozoflarından beri ahlak felsefesi başta olmak üzere din, siyaset, zihin felsefesi gibi alanlarda vicdan üzerine farklı felsefi teoriler geliştirilmiş olsa da her şeyden önce vicdan, ne tür bir insan olduğumuzu anlamamızın önemli bir kısmıdır. İnsan hayatı boyunca bir anlam üzerine kendini inşa etmeye çalışır. Bu süreçte ise onun diğer insanlarla, çevreyle, hayvanlarla ya da doğayla olan ilişkisi aslında bu kişinin nasıl bir insan olduğunu belirler. Tamamen dış faktörlerden bağımsız varlıklar olsaydık vicdani bir sisteme de şüphesiz ihtiyacımız olmazdı. Oysa öz-belirleyici, öz-tanımlayıcı bir süreç olan vicdani sistemin kuruluşu kendimizi bizim dışımızdaki varlıklar üzerinden, özellikle onlarla olan ilişkilerimiz üzerinden tanımlamamızı gerektirir. İyi ile kötü, doğru ile yanlış ontolojik olarak birbirlerine ihtiyaç duyarlar ve kendilerini birbirleri üzerinden tanımlarlar. Önemli olan hangi tarafta durduğumuza karar vermektir ve bu süreçte, yani öz-kimliğimizi bulmada, vicdan esastır.

Adres

İstanbul Medeniyet Üniversitesi, Eğitim Bilimleri Fakültesi, Türkce ve Sosyal Bilimler Eğitimi Bölümü, Türkçe Eğitimi ABD Cevizli Kampüsü, Kartal-İstanbul/TÜRKIYE e-posta: editor@rumelide.com
Address

İstanbul Medeniyet University, Faculty of Education Sciences,

Turkish and Social Scinces Education, Turkish Language Teaching

Education, Cevizli Campus, Kartal-İstanbul /TURKEY

e-mail: editor@rumelide.com 
Vicdanın bu kadar farklı değerlendirmelerinin bulunması aslında onun bir şekilde çoğulcu bir yapıya sahip olduğunun göstergesidir. Fakat bu kadar çoğul tanımın yine de bazı ortak özelliklerinin bulunması özellikle bu ortaklıklar üzerinden oluşturulması gereken bir vicdani sistemi kaçınılmaz kılar. Vicdanın derinden bağlı olduğu erdem ahlakı, "iyi olmak ve doğruyu gerçekleştirmekte, sadece doğru eylemi yapmanın değil uygun niyet, güdü ve duygulara sahip olmanın önemli olduğunu söyler" (Pojman ve Fieser, 2012, s.147). Bu nedenle, ancak aklın rehberliğinde ilerleyen niyet, güdü, duygu ve eylemin birlikteliği doğru bir vicdani sistem yaratabilir. Bu amaçla geliştirilmiş bir sağduyu da (prudence) muhtemel ve karmaşık durumlarda bizim doğru ahlaki kararlara ulaşmamızı sağlayacak bir erdem (Berg, 2012) olarak vicdani sistemde yerini alır.

Heidegger'e göre asıl insan, geçmiş ile geleceğin bir sentezi olan şimdinin varlığına hakim ve böylece vicdan sahibi insandır. İnsan vicdanı doğrultusunda özgürce eylerse, kaygı durumunu devam ettirirse ve kendi benliğine dönmesini sağlarsa vicdanı gelişebilir (Cevizci, 2015, s.1024). Bu nedenle vicdan sabit bir yapı değil, özelde insan ömrünü genelde tüm insanlığı kapsayan bir süreçtir. Vicdanın işlemesinde öznelliğin olduğu kadar kolektif bilincin yansımasının etkileri de unutulmamalıdır. Darwin'in evrimsel ilerleme ile birlikte vicdanın gelişimi fikri düşünüldüğünde insan ırkının vicdani gelişime doğru ilerlediği düşüncesi oldukça rahatlatıcıdır; fakat bu ilerlemenin altın tepside sunulacak bir ilerleme değil ancak insanın kendi çabasıyla ulaşabileceği bir seviye olduğunu hatırlamak gerekir.

Şüphesiz yaşamı başladığımız insan olarak bitirmeyiz. Bu noktada vicdani sistemin gelişmeye açı bir sistem olduğu unutulmamalıdır. Herkesin yanlış yaptığı doğrusu kaçınılmazdır; ama önemli olan yanlış kararlara karşı verdiğimiz tepkidir. Yanlışın karşısında vicdan azabı duyabiliyorsak ilerleme var, sistem çalışıyor demektir. Doğru karşısında vicdanımız rahatsa doğruların artacağının bir göstergesidir. Freud temelde insanın mutlu olmak için yaşadığını söyler; vicdani sistemi gelişmiş birey de ancak vicdani doğrular ile mutlu olabilir; çünkü zihnini ve kalbini asla terk etmeyen bir gözlemci onunla birliktedir. Bu noktada, pişmanlık, suçluluk, utanç duyguları olumsuz hisler olarak görülmemelidir. Çünkü pişman olabilen insana bundan sonraki öz muhakemesi sıklıkla bu pişmanlığı hatırlatacak, vicdan makinesinin çarklarının çalışmasına neden olacaktır. Bir kişinin artık aynı insan olmadığını söylemek onun hafızasında olan bir kaybı değil, ahlaki karakterinin ve inançlarının değişimini anlatır. Bu nedenle değişim ve gelişim her zaman mümkündür; istenilen bunun iyi ve doğruya doğru olmasıdır.

Sonuç olarak vicdani sistem, insanın kendi benliği ve benliğinin ahlaki gelişimi üzerine düşünmesiyle gelişir. Bunu yaparken hem benliğini hem ötekileri mümkün olduğunca nesnel bir şekilde değerlendirmeli, öznel yargılardan kaçınmalıdır. Bu noktada, insanın kendi davranışlarını başkasının gözünden izleme yöntemi yardımcı olabilir. Vicdani sistemin oturtulduğu değer sistemi erdemler üzerine kurulursa nesnelliğe yaklaşmak daha sağlam adımlarla mümkün olabilir. Vicdani kaygı geliştirebilen kişinin, eylemlerinin bencil olup olmadığını test etme imkânı da vardır. Bunu yaparken, tamamen dış dünyanın ortaya koyduğu doğrularla, onları sorgusuzca kabul ederek vicdani sistemi kurmak kadar, dış dünyadan kopuk, öznelliğe batmış bir vicdani sistem de tehlikelidir. Çözüm ikisi arasında kurulabilecek Aristoteles’in meşhur “ölçülülük” fikrinde yatıyor gibi. Aristoteles’in bunun tam bir ölçüsünü vermesi belki işi daha kolaylaştırırdı...

\section{Kaynakça}

Arendt, H. (1971). "Thinking and Moral Considerations". Social Research, Vol. 38, No.3, 417-446.

Berg, T. V. (2012). "What is Moral Conscience?". Homiletic\&Pastoral Review (ISSN o018-4268). http://www.hprweb.com/2012/01/what-is-moral-conscience/

Adres

İstanbul Medeniyet Üniversitesi, Eğitim Bilimleri Fakültesi, Türkce ve Sosyal Bilimler Eğitimi Bölümü, Türkçe Eğitimi ABD Cevizli Kampüsü, Kartal-İstanbul/TÜRKIYE e-posta: editor@rumelide.com
Address

İstanbul Medeniyet University, Faculty of Education Sciences,

Turkish and Social Scinces Education, Turkish Language Teaching

Education, Cevizli Campus, Kartal-İstanbul /TURKEY

e-mail: editor@rumelide.com 
Cengiz, Y.; Çınar, S. (Ed.). (2018). İslam Düşüncesinde Vicdan Kavramı. Ankara: Nobel.

Cevizci, A. (2015). Felsefe Tarihi: Thales'ten Baudrillard'a. İstanbul: Say.

Çelik, Ş. (2018). "Batı Felsefesi Tarihinde Genel Hatlarılla Vicdan”. İslam Düşüncesinde Vicdan Kavramı (Ed. Yunus Cengiz ve Selime Çınar). Ankara: Nobel.

Darwin, C. (1871). The Descent of Man, and Selection in Relation to Sex. Princeton: Princeton UP, 1981.

Dostoyevsky, F. (1866). Suç ve Ceza. İstanbul: Cem Yayınevi, 1995.

Erdoğdu, T. (2017). Özgürlükten Kurtulmak. İstanbul: Rumuz.

Fink, B. (1999). A Clinical Introduction to Lacanian Psychoanalysis-Theory and Technique. London: Harvard University Press.

Foucault, M. (1975). Discipline and Punish: The Birth of the Prison (Trans. by Alan Sheridan). New York: Vintage Books, 1979.

Foucault, M. (1980). Power and Knowledge: Selected Interviews and Other Writings 1972-1977 (Ed. by Colin Gordon). New York: Pantheon Books.

Freud, S. (1926). Psikopatoloji (Çev. Hakan Atalay). İstanbul: Payel Yayınevi, 1999.

Friedman, L. S. (2008). "Grief, Grief, Grief: Lord of the Flies". William Golding's Lord of the Flies (Edited by Harold Bloom). New York: Infobase Publishing, 59-70.

Fuss, P. (1964). “Conscience”. Ethics, Vol. 74, No. 2, 111-120.

Golding, W. (1954). Lord of the Flies. New York: Capricorn Books, 1959.

Golding, W. (1955). The Inheritors. London: Faber and Faber.

Hare, R. (1999). Without Conscience: The Disturbing World of the Psychopaths Among Us. New York\&London: The Guilford Press.

Kant, I. (1797). The Metaphysics of Morals. Cambridge: Cambridge UP, 1991.

Kant, I. (1781). Critique of Pure Reason (Translated by Paul Guyer and Allen Wood). Cambridge: Cambridge UP, 1998.

Kant, I. (1785). Groundwork of the Metaphysics of Morals (Trans. by Mary Gregor). Cambridge\&New York: Cambridge UP, 2006.

Lessing, D. (1974). The Memoirs of a Survivor. London: Picador, 1976.

Lessing, D. (1999). Mara ile Dann. İstanbul: Can Yayınları, 2011.

Myles, A. (1991). Doris Lessing: A Novelist with Organic Sensibility. New Delhi: Associated Publishing House.

Nietzsche, F. (1887). On the Genealogy of Morals. (Trans. by Walter Kaufmann and R.J. Hollingdale). New York: Random House, 1967.

Orwell, G. (1945). Animal Farm. Harmondsworth: Penguin Books, 2000.

Orwell, G. (1949). 1984. London. Penguin Books, 1990.

Pojman, L. P.; Fieser, J. (2012). Ethics: Discovering Right and Wrong. Boston: Wadsworth.

Raphael, D. D. (2007). The Impartial Spectator: Adam Smith's Moral Philosophy. Oxford: Oxford UP.

Ratzinger, J. (2010). “Conscience and Truth”. Communio, Vol. 37, 529-538.

Rousseau, J. J. (1921). Emile: Or on Education (Trans. by Barbara Foxley). New York: E. P. Dutton. Online Library of Liberty. http://oll.libertyfund.org/titles/rousseau-emile-or-education

Shakespeare, W. (1603). Hamlet. Oxford: Oxford UP, 1995.

Shakespeare, W. (1623). Macbeth. London: Penguin Books, 1990.

\footnotetext{
\begin{tabular}{r|l} 
Adres & $\begin{array}{l}\text { Address } \\
\text { İstanbul Medeniyet Üniversitesi, Eğitim Bilimleri Fakültesi, Türkçe }\end{array}$ \\
İstanbul Medeniyet University, Faculty of Education Sciences,
\end{tabular} ve Sosyal Bilimler Eğitimi Bölümü, Türkce Eğitimi ABD Cevizli Turkish and Social Scinces Education, Turkish Language Teaching Kampüsü, Kartal-İstanbul/TÜRKIYE $\quad$ Education, Cevizli Campus, Kartal-İstanbul /TURKEY e-posta: editor@rumelide.com $\mid$ e-mail: editor@rumelide.com
} 
Sorabji, R. (2014). Moral Conscience Through the Ages. Oxford: Oxford UP.

Spohn, W C. (2000). “Conscience and Moral Development”. Theological Studies 61, 122-138.

Strohm, P. (2011). Conscience: A Very Short Introduction. Oxford: Oxford UP.

Thomson, J. J. (1971). “A Defence of Abortion”. Applied Ethics (Ed. Peter Singer). Oxford: Oxford UP, 1986.

Tüzün, M. (2011). Sevginin Son Kanıtı. Ankara: Arkadaş.

Ylldız, F. (2015). "Freud'da Ahlak Duygusunun Kaynağı ve Kant'in Ahlak Düşüncesi”. FLSF (Felsefe ve Sosyal Bilimler Dergisi), Sayı: 19, 137-151. 